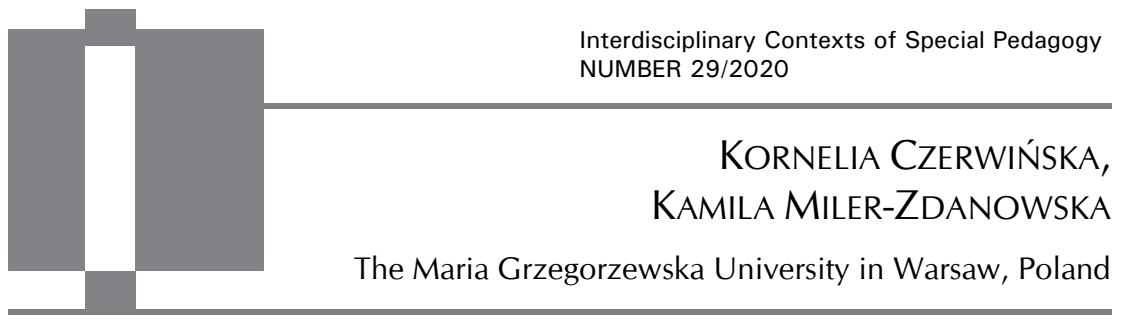

\title{
Educating teachers of the visually impaired in the context of educational and social changes $-a$ research report
}

\begin{abstract}
Kornelia Czerwińska, Kamila Miler-Zdanowska, Educating teachers of the visually impaired in the context of educational and social changes - a research report. Interdisciplinary Contexts of Special Pedagogy, no. 29, Poznań 2020. Pp. 45-73. Adam Mickiewicz University Press. ISSN 2300-391X. e-ISSN 2658-283X. DOI: https://doi. org/10.14746/ikps.2020.29.03

Changes in the ways of performing professional roles of special education teachers entail the need to develop new solutions for academic education for teachers of the visually impaired. The assessment of the content and forms of the previously proposed education for teachers of the visually impaired from the perspective of the usefulness of their professional competencies may be helpful in the determination of the needed directions of changes in this respect. The aim of the article is to describe and analyse the results of comparative research on visual impairment pedagogy graduates educated in the system of 5-year uniform master's studies and 3-year bachelor's studies, concerning the course of their educational and professional paths.
\end{abstract}

KEY WORDS: special education teacher, teacher of the visually impaired, professional roles 


\section{Introduction}

Nowadays, the requirements and expectations for the profession of a teacher of the visually impaired are high because of a significant broadening and diversification of fields of special education. This education has lost its status of an exclusively school education, concerning primarily special school and education centres educating children and youth with a specific type of disability. A number of tasks in the field of special education are currently performed in numerous centres and institutions of different type operating outside the education system, because the area of interest of this subdiscipline of education includes the full life cycle of people exposed to exclusion because of physical impairment. ${ }^{1}$ In turn, supporting the development of these people during childhood and adolescence more and more often takes place in public schools resulting from the popularization of the idea of inclusive education.

The constantly growing catalogue of professional tasks assigned to special education teachers implies the need to modify the system of preparing this group for work and to provide conditions favouring the effective improvement of competencies during its execution. The review of pedeutological texts ${ }^{2}$ proves that as early as in the 1980s, the need to introduce changes in the national model of education of special education teachers, which would enable the acquisition of interdisciplinary knowledge and development of skills necessary in new forms of work, was recognised. Gradual transformations within the population of people with disabilities was foreseen and it was postulated to depart from academic background focused only on performing the basic functions of a teacher within a school facility.

The systematic reduction of segregation in the education of students with disabilities has intensified the process of developing

${ }^{1}$ M. Kupisiewicz, Pedagog specjalny - człowiek o wyjatkowych predyspozycjach osobowościowych, profesjonalista posiadajacy rozległa, interdyscyplinarna wiedze $i$ umiejętności, „Studia z Teorii Wychowania” 2016, no. 4(17), pp. 173-174.

2 K. Parys, S. Olszewski, Ewolucja pogląów na temat kształcenia pedagogów specjalnych w Polsce, „Niepełnosprawność. Półrocznik naukowy” 2009, no. 1, pp. 103-112. 
a new strategy for the education of special education teachers, as the available forms of teaching this group of students constitute one of the main determinants of the formation of the labour market for educators. ${ }^{3}$ Preparing educators to perform numerous key functions within integrated and public schools (including the role of a support teacher, a consultant, an assistant, a diagnostician, an expert conducting rehabilitation and therapeutic activities) ${ }^{4}$, in which both highly specialised professional qualifications related to the specificity of a given disability, and the ability to work in groups with a significant degree of diversity are important, has become crucial. Working in non-segregated conditions require the special education teacher to be particularly competent in coordinating diagnostic and rehabilitation activities, as well as use multi-specialised knowledge to satisfy special educational needs of students. The effectiveness of such work depends largely on the level of interpersonal skills, including the ability to interact with other people and cope with difficult situations, as well as to be empathic to understand the situation of pupils and their families. ${ }^{5}$ Reflectiveness, flexibility in the use of various didactic strategies, readiness to use the experience of other teachers, desire to constantly improve professional skills are some of numerous features that should characterise future teachers of inclusive education. ${ }^{6}$ Because of the dynamic changes in the socioeducational space generating new functions for schools, contemporary concepts of teaching educators are constantly evolving in the search for optimal solutions, the development of which is extremely difficult as a result of the number and variety of services in the field

${ }^{3}$ J. Pańczyk, Ksztatcenie pedagogów specjalnych w Polsce, [in:] Historyczne dyskursy nad pedagogika specjalna, ed. J.J. Błeszyński, D. Baczała, J. Binnebesel, Wydawnictwo Naukowe WSEZ, Łódź 2008, pp. 52-53.

${ }^{4}$ D.D. Smith, Pedagogika specjalna, volume I, Wydawnictwo APS, Wydawnictwo Naukowe PWN, Warsaw 2009, pp. 85-87.

${ }^{5} \mathrm{M}$. Chodkowska, Razem damy sobie radę! W drodze do zintegrowanego spoteczeństwa, WSiP, Warsaw 2009, pp. 33-40.

${ }^{6}$ I. Chrzanowska, Edukacja wtączająca - wyzwanie dla kompetencji pedagogów specjalnych, „Studia Edukacyjne” 2018, no. 48, pp. 27-28. 
of special education provided to many entities. From 1981, academic education in the field of special education was carried out in the form of 5-year uniform master's studies, and since 1999, in accordance with the assumptions of the Bologna Process, a modification of uniform studies into two-level studies, carried out in the form of a 3-year first cycle degree program (bachelor's degree) and a 2-year second cycle degree program (master's degree) has been introduced. Although the adoption of this new education model was aimed at providing high quality education, increasing the employment rate of graduates and their mobility, the introduction of proBologna changes in preparing special educators and teachers for the profession was criticised in the environment. The lack of attention to clear program separation between the two levels of studies related to different areas of graduate competencies was emphasised. The schematism of the adopted National Qualifications Framework and excessive focus on the effects of the didactic process expressed in the form of operationalised messages and skills, and as a consequence significant difficulties in the development of a reflective, critical and creative approach to future professional activities were pointed out. For the fear of too low competencies acquired at individual cycles of studies in relation to the constantly expanding scope of professional activity of special educators, a postulate to restore 5-year uniform master's studies was put forward.7

Problems with the elaboration of curriculum content taught at bachelor's and master's studies in a manner corresponding to the current requirements of the labour market were noticed especially in those specialities where the priority issue in the acquisition of professional skills are numerous practical, simulation, out-of-classroom activities in small groups and the opportunity to learn the skills of experienced teachers and rehabilitators as part of lesson observation, study visits, student internships. This category of specialisa-

7 Z. Janiszewska-Nieścioruk, Trudności zwiąane z implementacją probolońskich zmian w ksztatceniu pedagogów i nauczycieli, „Niepełnosprawność i Rehabilitacja” 2013, no. 1, pp. 42-53. 
tions includes visual impairment pedagogy, which includes specialists involved in education, rehabilitation and multi-aspect support for the development of children, adolescents and adults with visual impairment. Teachers of the visually impaired work with a wide range of people with high heterogeneity of educational and developmental needs 8 , undertaking various roles in different types of school institutions, rehabilitation centres, and non-governmental organizations. In some cases, a teacher of the visually impaired is the main specialist working with a blind or partially sighted person and coordinating the activities of other professionals, while in others he acts as a consultant, advisor, expert conducting rehabilitation activities, belonging to an interdisciplinary team. ${ }^{9}$ The roles and responsibilities of teachers of the visually impaired are considered unique and require special predispositions enabling the effective use of a wide base of professional knowledge in everyday practice, including the ability to flexibly respond to the changing conditions and needs of pupils and the ability to use highly personalised educational and rehabilitation strategies. ${ }^{10}$

Uniform master's studies lasting 5 years allowed for the understanding of current state of scientific knowledge regarding individual aspects of psychosocial functioning of the blind and partially sighted of various ages, as well as equipped students with practical

${ }^{8}$ K.E. Wolffe, S.Z. Sacks, A.L. Corn, J.N. Erin, K.M. Huebner, S. Lewis, Teachers of students with visual impairments: What are they teaching?, "Journal of Visual Impairment \& Blindness" 2002, no. 96, pp. 293-303.

${ }_{9}^{9}$ S.M. Correa-Torres, J.J. Howell, Facing the challenges of itinerant teaching: Perspectives and suggestions from the field, "Journal of Visual Impairment \& Blindness" 2004, no. 98(7), pp. 420-433.

${ }^{10}$ Cf. M. Zaorska, Tyflopedagog wobec problemu aktywności życiowej - zawodowej i prozawodowej osób dorostych z niepetnosprawnością wzrokowa, Wydawnictwo Edukacyjne „Akapit”, Torun 2015, pp. 93-98. S.J. Spungin, K.A. Ferrell, M. Monson, The role and function of the teacher of students with visual impairments. Position paper of the Division on Visual Impairments, Council for Exceptional Children. Arlington, VA 2016. M. Zaorska, Aktywność społeczna osób dorostych niepetnosprawnych wzrokowo - możliwości i ograniczenia, [in:] Wybrane konteksty i wyzwania wspótczesnej pedagogiki specjalnej, ed. K. Barłóg, Wydawnictwo URz, Rzeszów 2017, pp. 27-35. 
skills in making functional diagnosis and conducting therapeutic classes in the field of spatial orientation and mobility, vision rehabilitation, Braille learning, graphic education, everyday activities, and use of assistive technology. The number of workshop classes carried out at the university and in institutions specialising in the work with people with visual impairment created the opportunity to learn the specific nature of didactic and rehabilitation activities with this group and to test acquired praxeological skills in practice. The introduction of a two-stage study model has caused a number of problems in providing future teachers of the visually impaired with full theoretical and practical background to take up employment in various environments, including in particular the reduction of the scope of curriculum content related to individual visual impairment pedagogy subdisciplines and limitation of student internships in continuous form. It should be noted that the lack of development opportunities of broad competencies in the field of rehabilitation of people with visual impairment may hinder graduates from effective execution of more and more professional tasks, especially in integrated and public schools. ${ }^{11}$

Academic centres preparing future teachers of the visually impaired for work have developed a diversified educational offer at individual levels of study. For example, the Maria Grzegorzewska University in Warsaw, which constitutes the area of research presented in this article, allowed for the acquisition, as part of the bachelor's degree, in addition to the qualifications in early childhood education, of full visual impairment pedagogy competence and skills in the area of spatial orientation and mobility of people with visual impairment. At the 2-year master's studies, curriculum content focused primarily on issues related to vision rehabilitation of partially sighted people. The multitude of currently available forms of education for teachers of the visually impaired education,

11 K. Czerwińska, Nauczyciel ucznia z niepetnosprawnościa wzroku - kierunki zmian w polskim systemie edukacji, [in:] Nauczyciel we wspótczesnej edukacji. Diagnoza - Rozwój - Zmiana, ed. M. Kamińska, Z.P. Kruszewski, A. Gretkowski, B. Skałbania, Oficyna Wydawnicza Szkoły Wyższej im. D. Kukla, Difin, Warsaw 2016, pp. 351-365. 
and the considerable program diversification of individual educational offers (bachelor's degree, master's degree, postgraduate education, qualifying courses) resulted in the fact that teachers of the visually impaired currently active on the domestic labour market, form a group with different professional qualifications and competencies. ${ }^{12}$ Therefore, it is fully justified to undertake scientific analyses concerning the professional situation of teachers of the visually impaired with different educational background, including learning their opinions on the importance and usefulness of knowledge and skills acquired during academic education. Exploratory research devoted to these issues are conducted in numerous countries ${ }^{13}$, and they indicate, among others, the problems related to: the need to expand university curricula with the content related to work with blind and partially sighted students with additional dysfunctions, the need to increase the quantity and number of types of practical classes, the development of interpersonal skills crucial in teamwork, discussing issues related to cultural, ethnic and cultural diversity to a greater extent than previously. The proposals submitted by professionally active teachers of the visually impaired included also the need for permanent organisation of short trainings, workshops, courses and thematic panels regarding selected, detailed problems in the field of education and rehabilitation of people with visual impairment.

12 M. Dycht, Edukacja włączająca uczniów z dysfunkcją wzroku w Polsce - wdrażanie zobowiązań i analiza wątków zaniedbanych, "Niepełnosprawność i Rehabilitacja” 2015, no. 2 , p. 40 .

${ }^{13}$ Cf. J. Dote-Kwan, D. Chen, M. Hughes, A national survey of service providers who work with young children with visual impairments, "Journal of Visual Impairment \& Blindness” 2001, no. 95(6), pp. 325-337. N. Griffin-Shirley, A.K. Koenig, C.A. Layton, R.C. Davidson, L.K. Siew, A.R. Edmonds, M.C. Robinson, A survey of teachers of students with visual impairments: responsibilities, satisfactions, and needs, "RE:view" 2004, no. 36(1), pp. 7-20. P.A. Suvak, What do they really do? Activities of teachers of students with visual impairments, "RE:view" 2004, no. 36(1), pp. 22-31. A.D. Kesiktaş, A.G. Akcamete, The relationship of personnel preparation to the competence of teachers of students with visual impairments in Turkey, "Journal of Visual Impairment \& Blindness" 2011, no. 105(2), pp. 108-124. 
Because of the great practical usefulness of this type of analysis, as well as the currently ongoing changes in the national model of education of special educators, including the reintroduction of 5-year uniform master's studies in this field, a survey in two groups of graduates of visual impairment pedagogy who acquired professional qualifications as part of their bachelor's or master's degree was conducted.

\section{Methodological foundations of own research}

In order to analyse the professional situation of teachers of the visually impaired with different educational backgrounds, the following research questions were formulated:

- Are there any differences in the course of the career path of 5-year studies graduates and 3-year studies graduates of visual impairment pedagogy and is so, which issues do they include?

- Are there any differences in the evaluation of the usefulness of the professional competencies acquired during studies in the current job between 5-year studies graduates and 3-year studies graduates of visual impairment pedagogy and if so, which issues do they include?

In order to answer the posed research questions, a comparative analysis of the results of survey responses of two groups of graduates specialised in visual impairment pedagogy (5-year studies graduates and 3-year studies graduates) was conducted. To this end, statistical analyses using the IBM SPSS Statistics 25 package were performed. It was used to conduct chi square tests of independence and correlation analyses with Kendall's tau-b coefficient. The significance level was assumed as $\alpha=0.05$, although $p$ values in the range $0.05<p<0.1$ were interpreted as indicating significant results at the level of statistical tendency.

In the study, the diagnostic survey method was used, while the authors' version of the survey questionnaire, which was sent to respondents electronically as an online form was applied as the research tool. 
The questionnaire consisted of 18 questions, including 15 closedended and 3 open-ended questions. The thematic scope of the questions covered two groups of issues: the first concerned the evaluation of the quality of education within the specialisation of visual impairment pedagogy, the second focused on questions related to the professional career of graduates of this specialisation.

The study included 102 people, graduates specialised in visual impairment pedagogy of the Maria Grzegorzewska University in Warsaw Two groups were distinguished based on the type and form of completed studies. The first one, consisting of 68 people, included graduates who were educated in the system of uniform master's degree (5-year studies). The second group consisted of people who acquired professional qualifications as part of their bachelor's degree (3-year studies) and it included 44 people. Because of the nature and subject of the study, the selection of the sample was a nonprobability sampling and the size of groups resulted from the number of people who specialised in visual impairment pedagogy within a specific form of education.

Based on age, four subgroups have been distinguished. The largest subgroup, both among 3-year and 5-year studies graduates, were people between $26-30$ years of age $(60.3 \%$ for 5 -year studies, $72.7 \%$ for 3-year studies), and the smallest one, people between $36-40$ years of age (10.3\% for 5 -year studies, $0 \%$ for 3 -year studies). Another category describing the study group is the work experience with people with visual impairment. In this, also four subcategories have been created. Among the respondents, both in the group of 3 -year and 5-year studies graduates, more than half of the respondents were people working with blind and partially sighted people for less than 5 years $(66.2 \%$ for 5 -years studies, $56.8 \%$ for 3 -year studies). The smallest group among graduates of 5-year visual impairment pedagogy were people who had no professional experience. The analysis of the professional activity of the graduates specialised in visual impairment pedagogy showed that the majority of people after graduation improved their professional compe- 
tencies. Among the 5-year studies graduates, the most popular were courses and trainings (51.47\%), qualifying courses $(42.65 \%)$ and postgraduate studies $(10.59 \%)$. In turn, among the 3-year studies graduates, the most popular were master's studies $(77.3 \%)$, followed by courses and trainings (31.1\%), and qualifying courses $(18.2 \%)$. The presented data demonstrate that graduates of visual impairment pedagogy, regardless of the type of completed studies, are very active in broadening and developing their professional competencies. Detailed data is presented in Table 1.

Table 1. Research sample characteristics

\begin{tabular}{|l|c|c|c|c|}
\hline \multirow{2}{*}{} & \multicolumn{5}{|c|}{ 5-year studies graduates } & \multicolumn{2}{l|}{ 3-year studies graduates } \\
\cline { 2 - 5 } & $\mathrm{N}$ & $\%$ & $\mathrm{~N}$ & $\%$ \\
\hline Under 25 years old & 11 & 16.2 & 11 & 25.0 \\
\hline 26-30 years old & 41 & 60.3 & 32 & 72.7 \\
\hline $31-35$ years old & 9 & 13.2 & 1 & 2.3 \\
\hline 36-40 years old & 7 & 10.3 & 0 & 0.0 \\
\hline \multicolumn{5}{|c|}{ Work experience with people with visual impairment } \\
\hline No experience & 0 & 0.0 & 16 & 36.4 \\
\hline 1-5 years & 45 & 66.2 & 25 & 56.8 \\
\hline 5-10 years & 17 & 25.0 & 3 & 6.9 \\
\hline 11-15 years & 6 & 8.8 & 0 & 0.0 \\
\hline Total & 68 & 100 & 44 & 100 \\
\hline \multicolumn{5}{|c|}{ Forms of professional development } \\
\hline Master's degree & 0 & 0.0 & 34 & 77.3 \\
\hline Postgraduate education & 14 & 20.59 & 8 & 17.8 \\
\hline Qualifying courses & 29 & 42.65 & 9 & 18.2 \\
\hline Courses, trainings, workshops & 35 & 51.47 & 14 & 31.1 \\
\hline Other & 18 & 26.47 & 0 & 0.0 \\
\hline
\end{tabular}

Source: own research. 


\section{Results of the study}

Education for the profession of a teacher of the visually impaired, apart from the necessity to learn theoretical knowledge, is also characterised by the need to master key practical skills needed in working with blind and partially sighted people (including the ability to read and write Braille, the ability to correctly adapt educational materials, the ability to conduct functional assessment of vision, the ability to teach methods and techniques of sightless movement, etc.).

The respondents were asked about the usefulness of visual impairment pedagogy competencies acquired during the studies in their professional work. Analysis of the responses of both groups of graduates showed that there are statistically significant differences

Table 2. A contingency table with the results of the chi square test for the relationship between the type of university education and opinion concerning visual impairment pedagogy competencies acquired during the studies

\begin{tabular}{|c|c|c|c|c|c|c|}
\hline \multirow{2}{*}{\multicolumn{2}{|c|}{$\begin{array}{l}\text { Did visual impairment } \\
\text { pedagogy competencies } \\
\text { acquired during the studies } \\
\text { prove sufficient in your } \\
\text { professional work? }\end{array}$}} & \multicolumn{2}{|c|}{ Group } & \multirow{2}{*}{$\begin{array}{l}\text { Likelihood } \\
\text { function }\end{array}$} & \multirow[b]{2}{*}{$\mathrm{p}$} & \multirow{2}{*}{$\begin{array}{c}\text { Cramér's } \\
\text { V }\end{array}$} \\
\hline & & $\begin{array}{l}\text { 5-year } \\
\text { studies }\end{array}$ & $\begin{array}{l}\text { 3-year } \\
\text { studies }\end{array}$ & & & \\
\hline \multirow{2}{*}{ Definitely not } & $\mathrm{N}$ & 0 & 2 & \multirow{10}{*}{8.80} & \multirow{10}{*}{0.066} & \multirow{10}{*}{0.27} \\
\hline & $\%$ & 0.0 & 4.5 & & & \\
\hline \multirow{2}{*}{ Rather not } & $\mathrm{N}$ & 2 & 1 & & & \\
\hline & $\%$ & 3.0 & 2.3 & & & \\
\hline \multirow{2}{*}{ Difficult to say } & $\mathrm{N}$ & 7 & 9 & & & \\
\hline & $\%$ & 10.6 & 20.5 & & & \\
\hline \multirow{2}{*}{ Rather yes } & $\mathrm{N}$ & 45 & 20 & & & \\
\hline & $\%$ & 68.2 & 45.5 & & & \\
\hline \multirow{2}{*}{ Definitely yes } & $\mathrm{N}$ & 12 & 12 & & & \\
\hline & $\%$ & 18.2 & 27.3 & & & \\
\hline
\end{tabular}

Source: own research. 
between the study groups. Among 5-year studies graduates there is a higher percentage of people agreeing with the statement that the competencies acquired during the studies are sufficient to perform professional work compared to 3-year studies graduates. This relationship turned out to be significant at the level of statistical tendency. It is a relationship of weak correlation. Detailed answers of the respondents are presented in Table 2.

Graduates of visual impairment pedagogy participating in the study were also asked to identify strong and weak points of education during their visual impairment pedagogy specialisation. Both 5-year and 3-year visual impairment pedagogy graduates have indicated the expertise of teaching staff and practical classes as the strongest elements of their education. Opinions of graduates in both groups of surveyed students are presented in Figure 1.
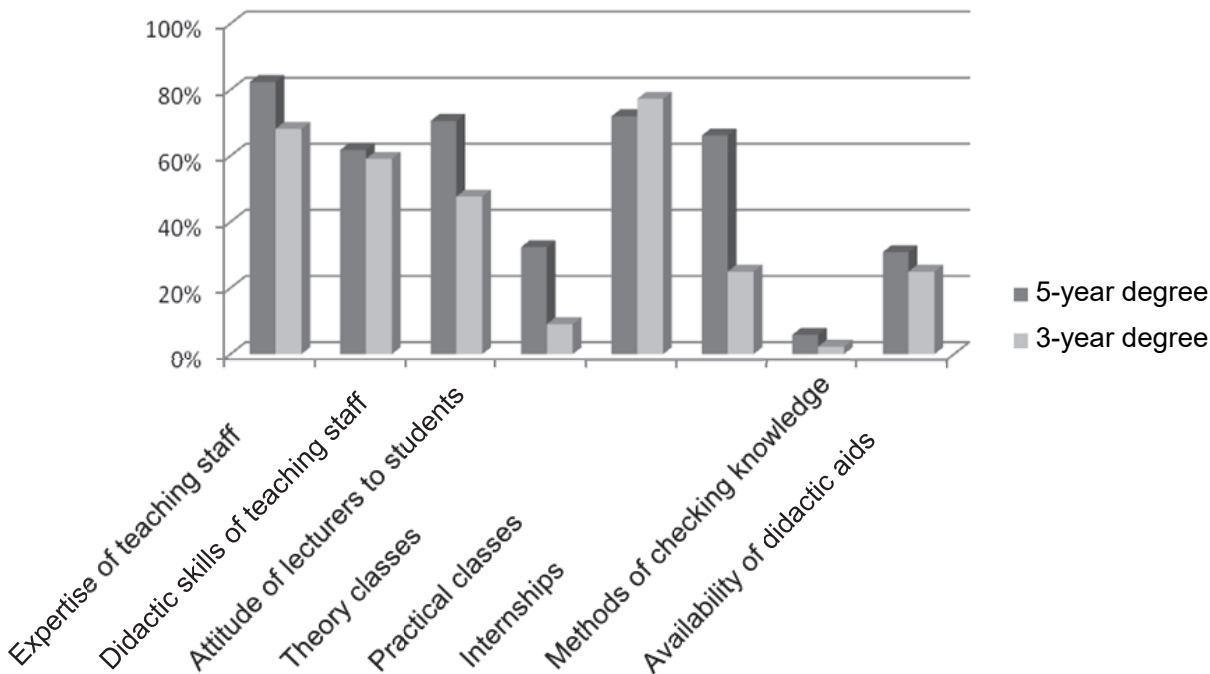

Fig. 1. Elements of education constituting the strongest point of the specialisation in visual impairment pedagogy based on the opinions of 5-year and 3-year studies graduates 
Table 3. A contingency table with the results of the chi square test for the relationship between the type of university education and opinion of the graduates concerning strong points of the specialisation in visual impairment pedagogy

\begin{tabular}{|c|c|c|c|c|c|c|c|}
\hline \multirow{2}{*}{\multicolumn{3}{|c|}{$\begin{array}{l}\text { Which elements of the study were } \\
\text { the strongest points of the specialisa- } \\
\text { tion in visual impairment pedagogy? }\end{array}$}} & \multicolumn{2}{|c|}{ Group } & \multirow[b]{2}{*}{$X^{2}$} & \multirow[b]{2}{*}{$\mathrm{p}$} & \multirow[b]{2}{*}{ phi } \\
\hline & & & \multirow{2}{*}{$\begin{array}{c}\begin{array}{c}5 \text {-year } \\
\text { studies }\end{array} \\
12 \\
\end{array}$} & \multirow{2}{*}{$\begin{array}{c}\begin{array}{c}3 \text {-year } \\
\text { studies }\end{array} \\
14 \\
\end{array}$} & & & \\
\hline \multirow{4}{*}{$\begin{array}{l}\text { Expertise of teaching } \\
\text { staff }\end{array}$} & \multirow{2}{*}{ no } & $\mathrm{N}$ & & & \multirow{4}{*}{3.01} & \multirow{4}{*}{0.083} & \multirow{4}{*}{0.16} \\
\hline & & $\%$ & 17.6 & 31.8 & & & \\
\hline & \multirow{2}{*}{ yes } & $\mathrm{N}$ & 56 & 30 & & & \\
\hline & & $\%$ & 82.4 & 68.2 & & & \\
\hline \multirow{4}{*}{$\begin{array}{l}\text { Didactic skills of } \\
\text { teaching staff }\end{array}$} & \multirow{2}{*}{ no } & $\mathrm{N}$ & 26 & 18 & 0.08 & 0.777 & 0.02 \\
\hline & & $\%$ & 38.2 & 40.9 & & & \\
\hline & \multirow{2}{*}{ yes } & $\mathrm{N}$ & 42 & 26 & & & \\
\hline & & $\%$ & 61.8 & 59.1 & & & \\
\hline \multirow{4}{*}{$\begin{array}{l}\text { Attitude of lecturers } \\
\text { to students }\end{array}$} & \multirow{2}{*}{ no } & $\mathrm{N}$ & 20 & 23 & \multirow{4}{*}{5.90} & \multirow{4}{*}{0.015} & \multirow{4}{*}{0.23} \\
\hline & & $\%$ & 29.4 & 52.3 & & & \\
\hline & \multirow{2}{*}{ yes } & $\mathrm{N}$ & 48 & 21 & & & \\
\hline & & $\%$ & 70.6 & 47.7 & & & \\
\hline \multirow{4}{*}{ Theory classes } & \multirow{2}{*}{ no } & $\mathrm{N}$ & 46 & 40 & \multirow{4}{*}{8.11} & \multirow{4}{*}{0.004} & \multirow{4}{*}{0.26} \\
\hline & & $\%$ & 67.6 & 90.9 & & & \\
\hline & \multirow{2}{*}{ yes } & $\mathrm{N}$ & 22 & 4 & & & \\
\hline & & $\%$ & 32.4 & 9.1 & & & \\
\hline & & $\mathrm{N}$ & 19 & 10 & & & \\
\hline & no & $\%$ & 27.9 & 22.7 & & 0538 & \\
\hline Practical classes & & $\mathrm{N}$ & 49 & 34 & 0.37 & 0.538 & 0.05 \\
\hline & yes & $\%$ & 72.1 & 77.3 & & & \\
\hline & no & $\mathrm{N}$ & 23 & 33 & & & \\
\hline & no & $\%$ & 33.8 & 75.0 & 1811 & م000 & 040 \\
\hline Internships & & $\mathrm{N}$ & 45 & 11 & 18.11 & 0.000 & 0.40 \\
\hline & yes & $\%$ & 66.2 & 25.0 & & & \\
\hline & $\mathrm{no}$ & $\mathrm{N}$ & 64 & 43 & & & \\
\hline Methods of checking & no & $\%$ & 94.1 & 97.7 & 081 & 0366 & 008 \\
\hline knowledge & & $\mathrm{N}$ & 4 & 1 & 0.81 & 0.366 & 0.08 \\
\hline & yes & $\%$ & 5.9 & 2.3 & & & \\
\hline & & $\mathrm{N}$ & 47 & 33 & & & \\
\hline Availability & no & $\%$ & 69.1 & 75.0 & 045 & 0,501 & $0 \Omega 6$ \\
\hline of didactic aids & & $\mathrm{N}$ & 21 & 11 & 0.45 & 0.501 & 0.00 \\
\hline & yes & $\%$ & 30.9 & 25.0 & & & \\
\hline
\end{tabular}

Source: own research. 
In addition, it was found that among graduates of 5-year studies, a higher percentage of people who believe that the attitude of lecturers to students, theory classes and internships are the strongest elements of the specialisation in visual impairment pedagogy was observed, compared to 3-year studies graduates. These relationships turned out to be statistically significant. They are relationships of weak correlation. The answers of both study groups are presented in Table 3.

In turn, in terms of identifying the weakest points during their visual impairment pedagogy specialisation, both groups of students indicated theory classes. On the other hand, among 5-year studies graduates, a lower percentage of people who believe that internships, methods of checking knowledge and availability of didactic aids are the weakest elements of the specialisation in visual impairment
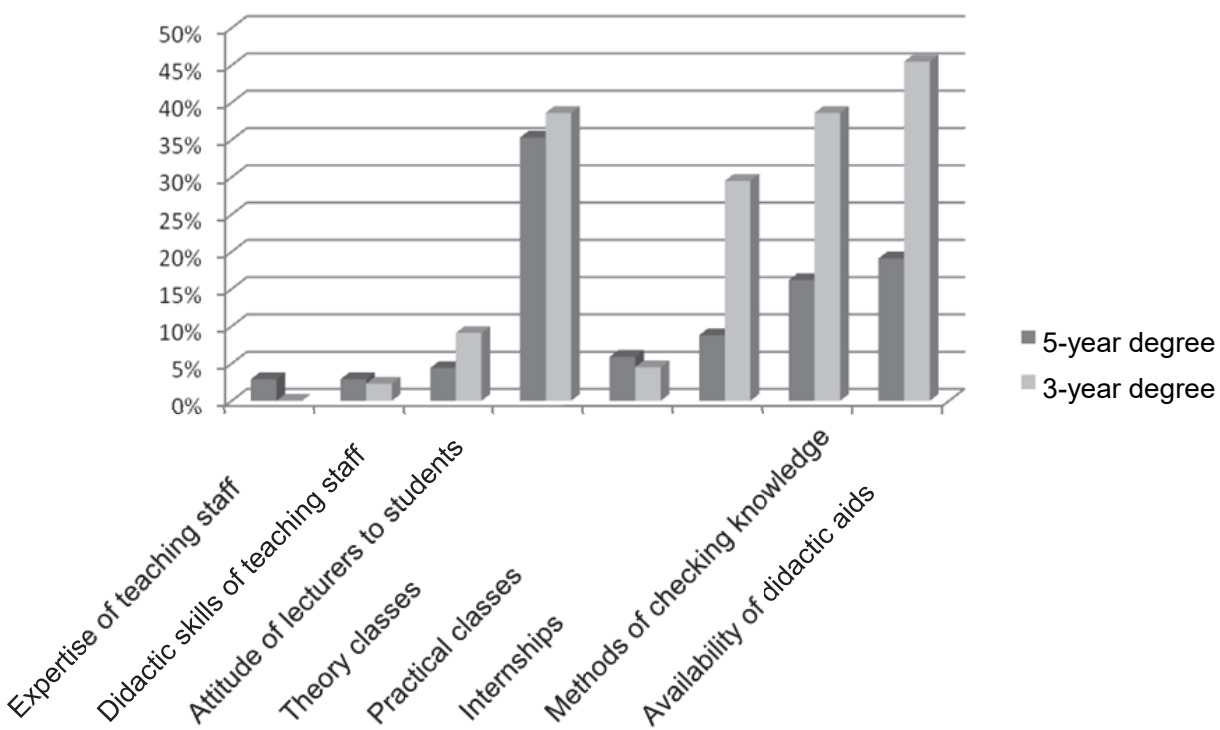

Figure 2. Elements of education constituting the weakest point of the specialisation in visual impairment pedagogy based on the opinions of 5-year and 3-year studies graduates 
Table 4. A contingency table with the results of the chi square test for the relationship between the type of university education and opinion of the graduates concerning weak points of the specialisation in visual impairment pedagogy

\begin{tabular}{|c|c|c|c|c|c|c|c|}
\hline \multirow{2}{*}{\multicolumn{3}{|c|}{$\begin{array}{l}\text { Which elements of the study were } \\
\text { the weakest points of the specialisa- } \\
\text { tion in visual impairment pedagogy? }\end{array}$}} & \multicolumn{2}{|c|}{ Group } & \multirow[b]{2}{*}{$X^{2}$} & \multirow[b]{2}{*}{$\mathrm{p}$} & \multirow[b]{2}{*}{ phi } \\
\hline & & & \multirow{2}{*}{$\begin{array}{c}\begin{array}{c}5 \text {-year } \\
\text { studies }\end{array} \\
66\end{array}$} & \multirow{2}{*}{$\begin{array}{c}\begin{array}{c}\text { 3-year } \\
\text { studies }\end{array} \\
44\end{array}$} & & & \\
\hline \multirow{4}{*}{$\begin{array}{l}\text { Expertise of teaching } \\
\text { staff }\end{array}$} & \multirow{2}{*}{ no } & $\mathrm{N}$ & & & \multirow{4}{*}{1.31} & \multirow{4}{*}{0.251} & \multirow{4}{*}{0.10} \\
\hline & & $\%$ & 97.1 & $100.0 \%$ & & & \\
\hline & \multirow{2}{*}{ yes } & $\mathrm{N}$ & 2 & 0 & & & \\
\hline & & $\%$ & $2.9 \%$ & $0.0 \%$ & & & \\
\hline \multirow{4}{*}{$\begin{array}{l}\text { Didactic skills of } \\
\text { teaching staff }\end{array}$} & \multirow{2}{*}{ no } & $\mathrm{N}$ & 66 & 43 & \multirow{4}{*}{0.46} & \multirow{4}{*}{0.831} & \multirow{4}{*}{0.02} \\
\hline & & $\%$ & $97.1 \%$ & $97.7 \%$ & & & \\
\hline & \multirow{2}{*}{ yes } & $\mathrm{N}$ & 2 & 1 & & & \\
\hline & & $\%$ & $2.9 \%$ & $2.3 \%$ & & & \\
\hline \multirow{4}{*}{$\begin{array}{l}\text { Attitude of lecturers } \\
\text { to students }\end{array}$} & \multirow{2}{*}{ no } & $\mathrm{N}$ & 65 & 40 & \multirow{4}{*}{0.99} & \multirow{4}{*}{0.318} & \multirow{4}{*}{0.09} \\
\hline & & $\%$ & 95.6 & 90.9 & & & \\
\hline & \multirow{2}{*}{ yes } & $\mathrm{N}$ & 3 & 4 & & & \\
\hline & & $\%$ & 4.4 & 9.1 & & & \\
\hline \multirow{4}{*}{ Theory classes } & \multirow{2}{*}{ no } & $\mathrm{N}$ & 44 & 27 & \multirow{4}{*}{0.12} & & \\
\hline & & $\%$ & 64.7 & 61.4 & & م7ר & 003 \\
\hline & & $\mathrm{N}$ & 24 & 17 & & 0.120 & 0.03 \\
\hline & yes & $\%$ & 35.3 & 38.6 & & & \\
\hline & & $\mathrm{N}$ & 64 & 42 & & & \\
\hline Practical clacsec & no & $\%$ & 94.1 & 95.5 & 009 & 0759 & $00 ?$ \\
\hline Practical classes & & $\mathrm{N}$ & 4 & 2 & 0.09 & 0.759 & 0.02 \\
\hline & yes & $\%$ & 5.9 & 4.5 & & & \\
\hline & & $\mathrm{N}$ & 62 & 31 & & & \\
\hline Internshins & no & $\%$ & 91.2 & 70.5 & 814 & 0004 & 027 \\
\hline internsnips & & $\mathrm{N}$ & 6 & 13 & 8.14 & 0.004 & \\
\hline & yes & $\%$ & 8.8 & 29.5 & & & \\
\hline & & $\mathrm{N}$ & 57 & 27 & & & \\
\hline Methods of checking & no & $\%$ & 83.8 & 61.4 & & & \\
\hline knowledge & & $\mathrm{N}$ & 11 & 17 & 7.18 & $0.00 \%$ & 0.25 \\
\hline & yes & $\%$ & 16.2 & 38.6 & & & \\
\hline & & $\mathrm{N}$ & 55 & 24 & & & \\
\hline Availability & no & $\%$ & 80.9 & 54.5 & & & \\
\hline of didactic aids & & $\mathrm{N}$ & 13 & 20 & 8.91 & 0.003 & 0.28 \\
\hline & yes & $\%$ & 19.1 & 45.5 & & & \\
\hline
\end{tabular}

Source: own research. 
pedagogy, was observed, compared to 3-year studies graduates. The observed differences turned out to be statistically significant. They are relationships of weak correlation. Detailed responses of the respondents are presented in Figure 2 and Table 4.

The period of university education, apart from the acquisition of praxeological competence, is also a period in which moral and personality competencies of future educators are formed. The surveyed graduates specialised in visual impairment pedagogy were also asked about this issue. As a result of the analyses, no statistically significant difference was observed between the responses of 5-year studies graduates and 3-year studies graduates concerning the question of whether the university education had a positive impact on their personal development. In both groups of surveyed graduates, an overwhelming majority confirmed that the university education had a positive impact on their personal development $(93.4 \%$ of 5 -year studies graduates, $97.8 \%$ of 3 -year studies graduates). The data are presented in Table 5.

However, a statistically significant difference was observed in the scope of personality traits listed by the respondents, which in their opinion developed significantly during their study of visual impair-

Table 5. A contingency table with the results of the chi square test for the relationship between the type of university education and the impact of visual impairment pedagogy studies on the personal development of graduates

\begin{tabular}{|c|c|c|c|c|c|c|}
\hline \multirow{2}{*}{\multicolumn{2}{|c|}{$\begin{array}{l}\text { Did the studies in visual } \\
\text { impairment pedagogy posi- } \\
\text { tively affect your personal } \\
\text { development? }\end{array}$}} & \multicolumn{2}{|c|}{ Group } & \multirow[b]{2}{*}{$\begin{array}{l}\text { Likelihood } \\
\text { function }\end{array}$} & \multirow[b]{2}{*}{$\mathrm{p}$} & \multirow[b]{2}{*}{$\begin{array}{c}\text { Cramér's } \\
\text { V }\end{array}$} \\
\hline & & $\begin{array}{l}5 \text {-year } \\
\text { studies }\end{array}$ & $\begin{array}{l}\text { 3-year } \\
\text { studies }\end{array}$ & & & \\
\hline \multirow{2}{*}{ Difficult to say } & $\mathrm{N}$ & 5 & 1 & \multirow{6}{*}{3.44} & \multirow{6}{*}{0.179} & \multirow{6}{*}{0.17} \\
\hline & $\%$ & 7.4 & 2.3 & & & \\
\hline \multirow{2}{*}{ Rather yes } & $\mathrm{N}$ & 32 & 16 & & & \\
\hline & $\%$ & 47.1 & 36.4 & & & \\
\hline \multirow{2}{*}{ Definitely yes } & $\mathrm{N}$ & 31 & 27 & & & \\
\hline & $\%$ & 45.6 & 61.4 & & & \\
\hline
\end{tabular}

Source: own research. 
Table 6. A contingency table with the results of the chi square test for the relationship between the type of university education and the opinion of graduates concerning the development of their personality traits during their studies

\begin{tabular}{|c|c|c|c|c|c|c|c|}
\hline \multirow{2}{*}{\multicolumn{3}{|c|}{$\begin{array}{l}\text { Which traits were influenced by } \\
\text { visual impairment pedagogy studies? }\end{array}$}} & \multicolumn{2}{|c|}{ Group } & \multirow[b]{2}{*}{$X^{2}$} & \multirow[b]{2}{*}{$\mathrm{p}$} & \multirow[b]{2}{*}{ phi } \\
\hline & & & \multirow{2}{*}{$\begin{array}{c}\begin{array}{c}5 \text {-year } \\
\text { studies }\end{array} \\
66\end{array}$} & \multirow{2}{*}{$\begin{array}{c}\begin{array}{c}3 \text {-year } \\
\text { studies }\end{array} \\
43 \\
\end{array}$} & & & \\
\hline \multirow{4}{*}{ None } & \multirow{2}{*}{ no } & $\mathrm{N}$ & & & \multirow{4}{*}{0.04} & \multirow{4}{*}{0.831} & \multirow{4}{*}{0.02} \\
\hline & & $\%$ & 97.1 & 97.7 & & & \\
\hline & \multirow{2}{*}{ yes } & $\mathrm{N}$ & 2 & 1 & & & \\
\hline & & $\%$ & 2.9 & 2.3 & & & \\
\hline \multirow{4}{*}{ Assertiveness } & \multirow{2}{*}{ no } & $\mathrm{N}$ & 44 & 38 & \multirow{4}{*}{6.39} & \multirow{4}{*}{0.011} & \multirow{4}{*}{0.23} \\
\hline & & $\%$ & 64.7 & 86.4 & & & \\
\hline & \multirow{2}{*}{ yes } & $\mathrm{N}$ & 24 & 6 & & & \\
\hline & & $\%$ & 35.3 & 13.6 & & & \\
\hline \multirow{4}{*}{ Thoroughness } & \multirow{2}{*}{ no } & $\mathrm{N}$ & 30 & 18 & \multirow{4}{*}{0.11} & \multirow{4}{*}{0.738} & \multirow{4}{*}{0.03} \\
\hline & & $\%$ & 44.1 & 40.9 & & & \\
\hline & \multirow{2}{*}{ yes } & $\mathrm{N}$ & 38 & 26 & & & \\
\hline & & $\%$ & 55.9 & 59.1 & & & \\
\hline \multirow{4}{*}{ Sensitivity } & \multirow{2}{*}{ no } & $\mathrm{N}$ & 24 & 22 & \multirow{4}{*}{2.38} & \multirow{4}{*}{0.122} & \multirow{4}{*}{0.14} \\
\hline & & $\%$ & 35.3 & 50.0 & & & \\
\hline & \multirow{2}{*}{ yes } & $\mathrm{N}$ & 44 & 22 & & & \\
\hline & & $\%$ & 64.7 & 50.0 & & & \\
\hline \multirow{4}{*}{ Resourcefulness } & no & $\mathrm{N}$ & 34 & 25 & & & \\
\hline & no & $\%$ & 50.0 & 56.8 & 049 & 0480 & 067 \\
\hline & & $\mathrm{N}$ & 34 & 19 & 0.49 & 0.480 & $0.6 \%$ \\
\hline & yes & $\%$ & 50.0 & 43.2 & & & \\
\hline & & $\mathrm{N}$ & 52 & 44 & & & \\
\hline Othor & no & $\%$ & 76.5 & 100.0 & 1207 & ( 001 & 032 \\
\hline Uther & & $\mathrm{N}$ & 16 & 0 & 12.07 & 0.001 & 0.32 \\
\hline & yes & $\%$ & 23.5 & 0.0 & & & \\
\hline
\end{tabular}

Source: own research.

ment pedagogy. Among the 5-year studies graduates, a higher percentage of people who believe that the studies had an impact on their assertiveness was noted, compared to 3-year studies graduates 
(this is a weak correlation). On the other hand, no such difference was observed concerning the remaining listed traits. Detailed statistics are presented in Table 6.

Subsequent questions included in the survey focused on the professional career of graduates. The surveyed respondents were asked whether they have ever worked and whether they currently work as a teacher of the visually impaired. The analysis of the provided answers demonstrated that in the group of 5-year studies graduates there is a higher percentage of teachers of the visually impaired (both of people who currently practice this profession and those who have ever done it), compared to 3 -year studies graduates. This relationship turned out to be statistically significant. It is a relationship of moderate correlation. The answers of both study groups are presented in Table 7.

The graduates specialised in visual impairment pedagogy were also asked to provide information on the nature of their current or previous work as a teacher of the visually impaired. The obtained information demonstrated that there is a statistically significant difference in this respect between both groups of graduates. Among

Table 7. A contingency table with the results of the chi square test for the relationship between the type of university education and the experience of work as a teacher of the visually impaired

\begin{tabular}{|c|c|c|c|c|c|c|c|}
\hline & $\mathrm{Gr}$ & & \multirow[b]{2}{*}{$X^{2}$} & \multirow[b]{2}{*}{$\mathrm{p}$} & \multirow[b]{2}{*}{ phi } \\
\hline & & & \multirow{2}{*}{$\begin{array}{c}\begin{array}{c}5 \text {-year } \\
\text { studies }\end{array} \\
17 \\
\end{array}$} & $\begin{array}{l}\text { 3-year } \\
\text { studies }\end{array}$ & & & \\
\hline \multirow{4}{*}{$\begin{array}{l}\text { Do you currently } \\
\text { work as a teacher of } \\
\text { the visually impaired? }\end{array}$} & & $\mathrm{N}$ & & 24 & \multirow{4}{*}{10.05} & \multirow{4}{*}{0.002} & \multirow{4}{*}{0.30} \\
\hline & no & $\%$ & 25.0 & 54.5 & & & \\
\hline & \multirow{2}{*}{ yes } & $\mathrm{N}$ & 51 & 20 & & & \\
\hline & & $\%$ & 75.0 & 45.5 & & & \\
\hline \multirow{4}{*}{$\begin{array}{l}\text { Have you ever } \\
\text { worked as a teacher } \\
\text { of the visually im- } \\
\text { paired? }\end{array}$} & \multirow{2}{*}{ no } & $\mathrm{N}$ & 7 & 18 & \multirow{4}{*}{14.44} & \multirow{4}{*}{0.000} & \multirow{4}{*}{0.35} \\
\hline & & $\%$ & 10.3 & 40.9 & & & \\
\hline & \multirow{2}{*}{ yes } & $\mathrm{N}$ & 61 & 26 & & & \\
\hline & & $\%$ & 89.7 & 59.1 & & & \\
\hline
\end{tabular}

Source: own research. 
Table 8. A contingency table with the results of the chi square test for the relationship between the type of university education and the nature of work executed as a teacher of the visually impaired

\begin{tabular}{|c|c|c|c|c|c|c|c|}
\hline \multirow{2}{*}{\multicolumn{3}{|c|}{$\begin{array}{l}\text { Which is/was the nature of your } \\
\text { work as a teacher of the visually } \\
\text { impaired? }\end{array}$}} & \multicolumn{2}{|c|}{ Group } & \multirow[b]{2}{*}{$X^{2}$} & \multirow[b]{2}{*}{$\mathrm{p}$} & \multirow[b]{2}{*}{ phi } \\
\hline & & & \multirow{2}{*}{$\begin{array}{c}\begin{array}{c}5 \text {-year } \\
\text { studies }\end{array} \\
56 \\
\end{array}$} & \multirow{2}{*}{$\begin{array}{c}\begin{array}{c}\text { 3-year } \\
\text { studies }\end{array} \\
37 \\
\end{array}$} & & & \\
\hline \multirow{4}{*}{$\begin{array}{l}\text { A teacher in a special } \\
\text { educational } \\
\text { institution }\end{array}$} & \multirow{2}{*}{ no } & $\mathrm{N}$ & & & \multirow{4}{*}{0.57} & \multirow{4}{*}{0.811} & \multirow{4}{*}{0.02} \\
\hline & & $\%$ & 82.4 & 84.1 & & & \\
\hline & \multirow{2}{*}{ yes } & $\mathrm{N}$ & 12 & 7 & & & \\
\hline & & $\%$ & 17.6 & 15.9 & & & \\
\hline \multirow{4}{*}{$\begin{array}{l}\text { A support teacher } \\
\text { in an integrated or } \\
\text { public educational } \\
\text { institution }\end{array}$} & \multirow{2}{*}{ no } & $\mathrm{N}$ & 57 & 41 & \multirow{4}{*}{2.13} & \multirow{4}{*}{0.144} & \multirow{4}{*}{0.13} \\
\hline & & $\%$ & 83.8 & 93.2 & & & \\
\hline & \multirow{2}{*}{ yes } & $\mathrm{N}$ & 11 & 3 & & & \\
\hline & & $\%$ & 16.2 & 6.8 & & & \\
\hline \multirow{4}{*}{$\begin{array}{l}\text { Vision therapist/ } \\
\text { vision rehabilitator }\end{array}$} & \multirow{2}{*}{ no } & $\mathrm{N}$ & 43 & 41 & \multirow{4}{*}{12.77} & \multirow{4}{*}{0.000} & \multirow{4}{*}{0.33} \\
\hline & & $\%$ & 63.2 & 93.2 & & & \\
\hline & \multirow{2}{*}{ yes } & $\mathrm{N}$ & 25 & 3 & & & \\
\hline & & $\%$ & 36.8 & 6.8 & & & \\
\hline \multirow{4}{*}{$\begin{array}{l}\text { Spatial orientation } \\
\text { teacher }\end{array}$} & \multirow{2}{*}{ no } & $\mathrm{N}$ & 30 & 39 & \multirow{4}{*}{22.34} & \multirow{4}{*}{0.000} & \multirow{4}{*}{0.44} \\
\hline & & $\%$ & 44.1 & 88.6 & & & \\
\hline & ves & $\mathrm{N}$ & 38 & 5 & & & \\
\hline & yes & $\%$ & 55.9 & 11.4 & & & \\
\hline & n & $\mathrm{N}$ & 60 & 43 & & & \\
\hline Therapist in an early & no & $\%$ & 88.2 & 97.7 & 325 & 071 & 017 \\
\hline support team & & $\mathrm{N}$ & 8 & 1 & & 0.071 & \\
\hline & yes & $\%$ & 11.8 & 2.3 & & & \\
\hline & & $\mathrm{N}$ & 58 & 43 & & & \\
\hline Boarding school & no & $\%$ & 85.3 & 97.7 & 466 & 0031 & 020 \\
\hline teacher & & $\mathrm{N}$ & 10 & 1 & 4.66 & & 0.20 \\
\hline & yes & $\%$ & 14.7 & 2.3 & & & \\
\hline & & $\mathrm{N}$ & 50 & 44 & & & \\
\hline Sthon & no & $\%$ & 73.5 & 100.0 & 1387 & م00 & 035 \\
\hline Utner & yes & $\mathrm{N}$ & 18 & 0 & $13.8 /$ & 0.000 & 0.35 \\
\hline & yes & $\%$ & 26.5 & 0.0 & & & \\
\hline
\end{tabular}

Source: own research. 
5-year studies graduates, there is a higher percentage of people who work as a vision therapist/vision rehabilitator, spatial orientation teacher and boarding school teacher than among 3-year studies graduates. However, no such difference in terms of other employment opportunities as a teacher of the visually impaired (teacher in a special school, a support teacher and a therapist in an early support team) was observed. The data are presented in Table 8.

Table 9. A contingency table with the results of the chi square test for the relationship between the type of university education and the satisfaction with the choice of and graduation from visual impairment pedagogy, and with the course of the previous professional career.

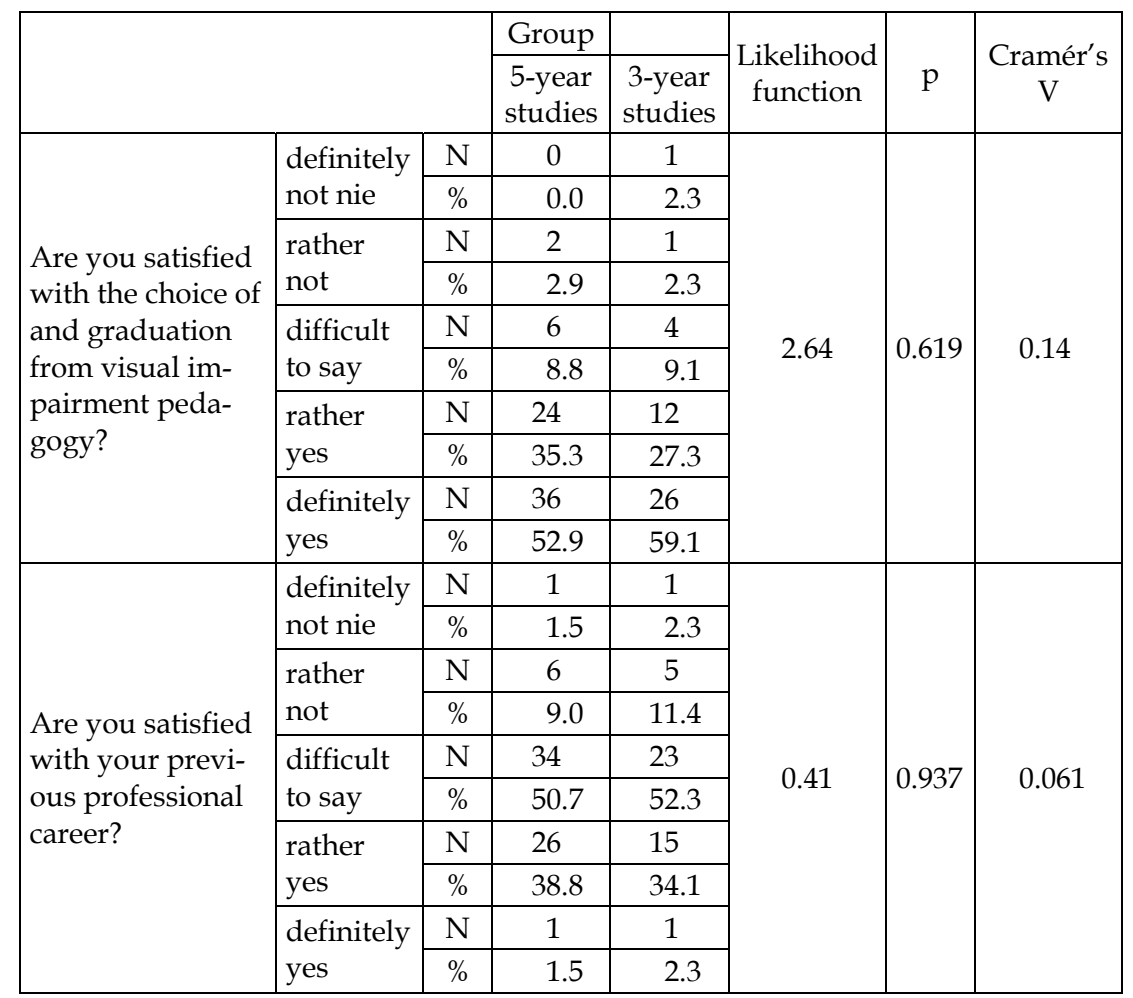

Source: own research. 
In order to check whether the surveyed 5-year studies graduates differ from 3-year studies graduates in terms of satisfaction with the choice of and graduation from visual impairment pedagogy, as well as with the course of their previous professional career, an analysis using the chi square test was performed. It showed that the correlation of both variables is not statistically significant. Both surveyed groups of graduates present the same level of satisfaction with the choice of and graduation from visual impairment pedagogy and with their previous professional career. Detailed answers of the surveyed respondents are presented in Table 9.

The surveyed respondents were also asked if they would choose the same studies in visual impairment pedagogy again. The obtained data demonstrated that among 5-year studies graduates, the percentage of people who would make such a choice again is higher than among 3-year studies graduates. This relationship turned out to be statistically significant. It is a relationship of moderate correlation. Detailed statistics are presented in Table 10.

Table 10. A contingency table with the results of the chi square test for the relationship between the type of university education and reselection of studies in visual impairment pedagogy

\begin{tabular}{|c|c|c|c|c|c|c|}
\hline \multirow{2}{*}{\multicolumn{2}{|c|}{$\begin{array}{c}\text { Would you choose studies } \\
\text { in visual impairment } \\
\text { pedagogy? }\end{array}$}} & \multicolumn{2}{|c|}{ Group } & \multirow{2}{*}{$\begin{array}{l}\text { Likelihood } \\
\text { function }\end{array}$} & \multirow[b]{2}{*}{$\mathrm{p}$} & \multirow{2}{*}{$\begin{array}{c}\text { Cramér's } \\
\text { V }\end{array}$} \\
\hline & & \multirow{2}{*}{$\begin{array}{c}\begin{array}{c}\text { 5-year } \\
\text { studies }\end{array} \\
0 \\
\end{array}$} & \multirow{2}{*}{$\begin{array}{c}\begin{array}{c}\text { 3-year } \\
\text { studies }\end{array} \\
3 \\
\end{array}$} & & & \\
\hline \multirow{2}{*}{ Definitely not } & $\mathrm{N}$ & & & \multirow{10}{*}{12.31} & \multirow{10}{*}{0.015} & \multirow{10}{*}{0.31} \\
\hline & $\%$ & 0.0 & 6.8 & & & \\
\hline \multirow{2}{*}{ Rather not } & $\mathrm{N}$ & 6 & 1 & & & \\
\hline & $\%$ & 8.8 & 2.3 & & & \\
\hline \multirow{2}{*}{ Difficult to say } & $\mathrm{N}$ & 9 & 11 & & & \\
\hline & $\%$ & 13.2 & 25.0 & & & \\
\hline \multirow{2}{*}{ Rather yes } & $\mathrm{N}$ & 25 & 9 & & & \\
\hline & $\%$ & 36.8 & 20.5 & & & \\
\hline \multirow{2}{*}{ Definitely yes } & $\mathrm{N}$ & 28 & 20 & & & \\
\hline & $\%$ & 41.2 & 45.5 & & & \\
\hline
\end{tabular}

Source: own research. 
In the course of the conducted analyses, it was also checked whether the surveyed groups of graduates differ in the level of identification with the profession of a teacher of the visually impaired. The obtained data demonstrated that among 5-year studies graduates, the percentage of people who identify with the profession of a teacher of the visually impaired is higher compared to 3-year studies graduates. This relationship turned out to be statistically significant. It is a relationship of weak correlation. The data are presented in Table 11.

Table 11. A contingency table with the results of the chi square test for the relationship between the type of university education and identification with the profession of a teacher of the visually impaired

\begin{tabular}{|c|c|c|c|c|c|c|}
\hline \multirow{2}{*}{\multicolumn{2}{|c|}{$\begin{array}{c}\text { Do you identify with the } \\
\text { profession of a teacher of the } \\
\text { visually impaired? }\end{array}$}} & \multicolumn{2}{|c|}{ Group } & \multirow{2}{*}{$\begin{array}{l}\text { Likelihood } \\
\text { function }\end{array}$} & \multirow[b]{2}{*}{$\mathrm{p}$} & \multirow{2}{*}{$\begin{array}{c}\text { Cramér's } \\
\text { V }\end{array}$} \\
\hline & & \multirow{2}{*}{$\begin{array}{c}\begin{array}{c}5 \text {-year } \\
\text { studies }\end{array} \\
0 \\
\end{array}$} & \multirow{2}{*}{$\begin{array}{c}\begin{array}{c}\text { 3-year } \\
\text { studies }\end{array} \\
2 \\
\end{array}$} & & & \\
\hline \multirow{2}{*}{ Definitely not } & $\mathrm{N}$ & & & \multirow{10}{*}{7.90} & \multirow{10}{*}{0.048} & \multirow{10}{*}{0.25} \\
\hline & $\%$ & 0.0 & 4.5 & & & \\
\hline \multirow{2}{*}{ Rather not } & $\mathrm{N}$ & 2 & 5 & & & \\
\hline & $\%$ & 2.9 & 11.4 & & & \\
\hline \multirow{2}{*}{ Difficult to say } & $\mathrm{N}$ & 23 & 16 & & & \\
\hline & $\%$ & 33.8 & 36.4 & & & \\
\hline \multirow{2}{*}{ Rather yes } & $\mathrm{N}$ & 43 & 21 & & & \\
\hline & $\%$ & 63.2 & $\begin{array}{ll}47.7 \\
\end{array}$ & & & \\
\hline \multirow{2}{*}{ Definitely yes } & $\mathrm{N}$ & 0 & 2 & & & \\
\hline & $\%$ & 0.0 & 4.5 & & & \\
\hline
\end{tabular}

Source: own research.

\section{Discussion of results}

Based on the analysis of the obtained research results, it can be observed that there are differences between graduates in visual impairment pedagogy educated in the system of 3-year and 5-year 
studies. These differences occur both in the evaluation of the usefulness of the professional skills obtained for the needs of the currently performed work during visual impairment pedagogy studies, as well as in the course of the professional career of both groups of graduates. The differences observed in the conducted research may result from a different study curriculum and may also be related to changes in the labour market. Graduates in visual impairment pedagogy educated in the system of uniform master's studies during their studies gained broader competencies in the field of supporting education and rehabilitation of people with visual impairment. In addition to basic visual impairment pedagogy competencies, they also obtained those which allow them to work as a teacher of spatial orientation and a vision rehabilitator. In contrast, graduates of bachelor's studies did not acquire competencies to work as a vision rehabilitator. Both groups of students also differed in terms of the number and duration of student internships (5-year studies graduates had more internships than 3-year studies graduates, in case of 5 -year studies graduated, they were also offered within a longer period). Therefore, the offered curriculum and the competencies acquired as part of the studies in two groups were slightly different. The variables mentioned above probably had an impact on the differences in the answers given to the question concerning the usefulness of the professional competencies acquired during the education, where the majority of 5-year studies graduates $(86.4 \%)$ confirmed their usefulness for the currently performed work. However, among those who graduated in 3-year visual impairment pedagogy, apart from people who recognised the usefulness of acquired competencies $(72.8 \%)$, there were also those who thought that they were definitely useless (4.5\%). Differences were also observed in the evaluation of student internships. Graduates of 5-year studies indicated them as one of the strong points of the specialisation $(66.2 \%)$, while graduates of 3-year studies did not share their opinion (only $25 \%$ of graduates recognised internships as a strong point of the specialisation).

The results of the study conducted among Polish teachers of the visually impaired correspond with the research conducted by American researchers. Teachers of the visually impaired belonging to the 
Association for the Education and Rehabilitation of Blind and Visually Impaired (AER) evaluated their curricula in terms of the usefulness of preparation for work with blind and visually impaired people. Among 392 respondents, $65 \%$ of teachers of the visually impaired were satisfied with the competencies obtained during their university education (30\% were very satisfied and $35 \%$ were rather satisfied) and only $2 \%$ were of a different opinion. ${ }^{1}$ In turn, Korean researchers conducting research among 190 teachers of students with visual impairment obtained different results. The authors of the study noticed a clear discrepancy between the evaluation of the importance of given professional competencies and their real application in visual impairment pedagogy practice. ${ }^{2}$

Differences resulting from different methods of education of teachers of the visually impaired among both groups of graduates are also evident in their decision of undertaking a job of a teacher of the visually impaired. As many as $75 \%$ of 5 -year studies graduates currently work in their profession, and $90 \%$ of respondents in this group have experience of working in this area. However, among 3 -year studies graduates, only $45.5 \%$ of the surveyed people currently work in their profession, and $60 \%$ have ever had such experience. In terms of the nature of a professional career undertaken by graduates, there are also visible differences between teachers of the visually impaired graduated from 5-year and 3-year studies. People who graduated from uniform master's studies usually undertake a job as vision therapists, spatial orientation teachers and boarding school teacher. Because of the dynamic socio-cultural changes and the change in the disability paradigm, the labour market for special educators, including teachers of the visually impaired is expanding. Their tasks are not only limited to supporting education (a job of

${ }^{1}$ N. Griffin-Shirley, A.K. Koenig, C.A. Layton, R.C. Davidson, L.K. Siew, A.R. Edmonds, M.C. Robinson, A survey of teachers of students with visual impairments: responsibilities, satisfactions, and needs, "RE:view" 2004, no. 36(1), pp. 7-20.

${ }^{2}$ H.-G. Lee, J.-H. Kim, J.-G. Kang, The Assessment of Professional Standard Competence of Teachers of Students with Visual Impairments, "International Journal of Special Education" 2008, no. 23, 2, pp. 33-46. 
a teacher at school), but more and more often they participate in the process of supporting the rehabilitation of people with visual impairment, providing specialised services in this area (teaching spatial orientation, teaching Braille, vision rehabilitation, etc.). Graduates of 3-year studies not equipped with this type of skills have fewer opportunities of the employment as a teacher of the visually impaired outside the education system. Differences in employment opportunities between two groups of graduates may also have an impact on the identification of respondents with the profession of a teacher of the visually impaired and the declaration of reselection of studies in visual impairment pedagogy. Among the 5-year studies graduates, as many as $63 \%$ of the respondents identify with the profession of a teacher of the visually impaired and $78 \%$ would reselect studies in visual impairment pedagogy. On the other hand studies, among 3-year graduates, 52\% declare their identification with the profession, and $66 \%$ of the respondents would choose their studies again. Graduates of uniform master's studies specialised in visual impairment pedagogy declare greater satisfaction with their studies, stronger identification with the profession and more often start a job corresponding to their education than graduates of 3-year studies (bachelor's degree).

However, both groups of graduates in visual impairment pedagogy (both 3-year studies graduates and 5-year studies graduates) are similar in terms of the level of satisfaction with the choice of studies in visual impairment pedagogy $(88.2 \%$ of 5 -year studies graduates, $86.4 \%$ of 3 -year studies graduates) and their professional careers $(40.3 \%$ of 5 -year studies graduates, $36.4 \%$ of 3 -year studies graduates). In addition, both groups show similarity in undertaking activities to improve their professional competencies. Respondents, regardless of the level of completed education, undertake professional improvement, most often based on short forms of development such as courses, trainings, workshops, but also on longer forms such as postgraduate studies. The results of the study conducted among Polish graduates in visual impairment pedagogy correspond to some extent to the results of the study conducted 
among Turkish and American teachers working with people with disabilities. In the study conducted by Nora Griffin-Shirley et al. ${ }^{3}$ most American teachers of the visually impaired declared participation in various forms of professional development. However, the actions they undertook had slightly different forms than those chosen by Polish teachers. Most often, they developed their professional competencies by reading professional publications (95\%), participation in conferences $(89 \%)$ and workshops $(84 \%)$, as well as trainings $(67 \%)$. On the other hand, post-graduate studies $(28 \%)$ were a less popular form of professional development. The differences between Polish and American teachers regarding the choice of forms of professional development may result from different systems of improving professional qualifications. The Polish system of teacher professional development is still mainly based on qualifying courses and postgraduate studies, as a result of which the teacher obtains various types of qualifications confirmed by an appropriate formal certificate. In western countries, however, more attention is paid to self-improvement and personal development through participation in conferences and reading professional publications. Nevertheless, both groups of teachers point to the usefulness of short forms of education such as trainings or workshops. Also in the study conducted by Ayse Dolunay Kesiktaş and Ayse Gonul Akcamete ${ }^{4}$ the surveyed teachers (the study included 224 teachers working with people with visual impairment) suggested the necessity and need for short forms improving professional competencies, with particular attention given to issues of working with people with multiple disabilities.

The professional situation of teachers of the visually impaired in the Polish education system is rarely a subject of scientific analysis.

${ }^{3}$ N. Griffin-Shirley, A.K. Koenig, C.A. Layton, R.C. Davidson, L.K. Siew, A.R. Edmonds, M.C. Robinson, A survey of teachers of students with visual impairments: responsibilities, satisfactions, and needs, "RE:view" 2004, no. 36(1), pp. 7-20.

${ }^{4}$ A.D. Kesiktaş, A.G. Akcamete, The relationship of personnel preparation to the competence of teachers of students with visual impairments in Turkey, "Journal of Visual Impairment \& Blindness" 2011, no. 105(2), pp. 108-124. 
The empirical data presented above has allowed for the identification of numerous interesting relationships between the course of academic education and professional activity of teachers of the visually impaired. Despite the significant cognitive and applicationrelated value of the study, it is also necessary to emphasise its limitations, mainly in terms of a relatively small sample. Because of the fact that the conducted study concerned only a selected group of Polish teachers of the visually impaired - graduates of the Maria Grzegorzewska University in Warsaw (this is one of several academic centres in Poland which educates teachers of the visually impaired) there is a need for further research of this type among a wider group of Polish teachers of the visually impaired.

\section{Summary}

The study conducted among graduates of 3-year and 5-year studies specialised in visual impairment pedagogy shows that the two studied groups differ in terms of the course of their educational and professional paths. The results of the study favour uniform master's studies, during which the student was provided with favourable conditions for the gradual acquisition of full specialist visual impairment pedagogy competencies. As a result of the introduction of the Bologna process and two-stage university education, it has become impossible to prepare a first-cycle education curriculum in such a way that the graduate obtains full professional theoretical and practical background to professionally support the development of people with visual impairment. The consequences of these changes in the area of academic education are evident in the presented research results both in terms of the number of people undertaking work as a teacher of the visually impaired, the nature of the undertaken professional activity, and the evaluation of the education system by the graduates in visual impairment pedagogy.

The constantly growing catalogue of professional tasks assigned to special education teachers implies the need to modify the system 
of preparing this group for work and to provide conditions favouring the effective improvement of competencies during its execution. Since 2019, universities in Poland have been implementing a 5-year special education teacher education system based on unified standards of teacher education. Based on the presented results of comparative research, the introduction of another modification in the field of educating special education teachers and the reintroduction of 5-year master's degree studies seems desirable and perfectly justified.

\section{References}

Chodkowska M., Razem damy sobie radę! W drodze do zintegrowanego społeczeństwa, WSiP, Warsaw 2009.

Chrzanowska I., Edukacja wtączająca - wyzwanie dla kompetencji pedagogów specjalnych, „Studia Edukacyjne” 2018, no. 48, pp. 23-32.

Correa-Torres S.M., Howell J.J., Facing the challenges of itinerant teaching: Perspectives and suggestions from the field, "Journal of Visual Impairment \& Blindness" 2004, no. 98(7), pp. 420-433.

Czerwińska K., Nauczyciel ucznia z niepetnosprawnościa wzroku - kierunki zmian w polskim systemie edukacji, [in:] Nauczyciel we wspótczesnej edukacji. Diagnoza Rozwój - Zmiana, ed. M. Kamińska, Z.P. Kruszewski, A. Gretkowski, B. Skałbania, Oficyna Wydawnicza Szkoły Wyższej im. D. Kukla, Difin, Warsaw 2016, pp. 351-365.

Dote-Kwan J., Chen D., Hughes M., A national survey of service providers who work with young children with visual impairments, "Journal of Visual Impairment \& Blindness" 2001, no. 95(6), pp. 325-337.

Dycht M., Edukacja włączająca uczniów z dysfunkcją wzroku w Polsce - wdrażanie zobowiązań i analiza wątków zaniedbanych, "Niepełnosprawność i Rehabilitacja” 2015, no. 2, pp. 34-49.

Griffin-Shirley N., Koenig A.K., Layton C.A., Davidson R.C., Siew L.K., Edmonds A.R., Robinson M.C., A survey of teachers of students with visual impairments: responsebilities, satisfactions, and needs, "RE:view" 2004, no. 36(1), pp. 7-20.

Janiszewska-Nieścioruk Z., Trudności związane z implementacja probolońskich zmian w kształceniu pedagogów i nauczycieli, „Niepełnosprawność i Rehabilitacja” 2013, no. 1, pp. 42-53.

Kesiktaş A.D., Akcamete A.G., The relationship of personnel preparation to the competence of teachers of students with visual impairments in Turkey, "Journal of Visual Impairment \& Blindness" 2011, no. 105(2), pp. 108-124. 
Kupisiewicz M., Pedagog specjalny - człowiek o wyjatkowych predyspozycjach osobowościowych, profesjonalista posiadający rozległa, interdyscyplinarna wiedze i umiejętności, „Studia z Teorii Wychowania” 2016, no. 4(17), pp. 173-186.

Lee H.-G., Kim J.-H., Kang J.-G., The Assessment of Professional Standard Competence of Teachers of Students with Visual Impairments, "International Journal of Special Education" 2008, no. 23, 2, pp. 33-46.

Pańczyk J., Kształcenie pedagogów specjalnych w Polsce, [in:] Historyczne dyskursy nad pedagogika specjalna, ed. J.J. Błeszyński, D. Baczała, J. Binnebesel, Wydawnictwo Naukowe WSEZ, Łódź 2008, pp. 51-63.

Parys K., Olszewski S., Ewolucja poglądów na temat ksztatcenia pedagogów specjalnych w Polsce, „Niepełnosprawność. Półrocznik naukowy” 2009, no. 1, pp. 103-112.

Smith D.D., Pedagogika specjalna, tom I, Wydawnictwo APS, Wydawnictwo Naukowe PWN, Warsaw 2009.

Spungin S.J., Ferrell K.A., Monson M., The role and function of the teacher of students with visual impairments, Position paper of the Division on Visual Impairments, Council for Exceptional Children. Arlington, VA 2016.

Suvak P.A., What do they really do? Activities of teachers of students with visual impairments, "RE:view" 2004, no. 36(1), pp. 22-31.

Wolffe K.E., Sacks S.Z., Corn A.L., Erin J.N., Huebner K.M., Lewis S., Teachers of students with visual impairments: What are they teaching?, "Journal of Visual Impairment \& Blindness" 2002, no. 96, pp. 293-303.

Zaorska M., Aktywność spoteczna osób dorostych niepetnosprawnych wzrokowo - możliwości i ograniczenia, [in:] Wybrane konteksty i wyzwania wspótczesnej pedagogiki specjalnej, ed. K. Barłóg, Wydawnictwo URz, Rzeszów 2017, pp. 27-42.

Zaorska M., Tyflopedagog wobec problemu aktywności życiowej - zawodowej i prozawodowej osób dorostych z niepetnosprawnościq wzrokowa, Wydawnictwo Edukacyjne "Akapit", Toruń 2015. 